\title{
THE ILO AND EAST CENTRAL EUROPE: INSIGHTS INTO THE EARLY POLISH AND CZECHOSLOVAK INTERWAR YEARS
}

\author{
NATALI STEGMANN \\ UNIVERSITÄT REGENSBURG
}

\begin{abstract}
The International Labour Organization (ILO) was a part of the international order established by the Treaty of Versailles, which considered social and labor policies as fundamental to the building of a modern peaceful world. Politically, the formation of the Polish and Czechoslovak nation states was also part of the new European order. This article explores the collaboration between the governments of those states and the ILO, concentrating on the intersections between the international standards put forward by the ILO and the institutional continuity of the German and Austrian social insurance systems in the region. It illuminates the so far underreported heritage of transnational policy-making. Analyzing the work of the ILO's national Correspondence Offices in Warsaw and Prague, the ratification of labor standards, and the enacting of social legislation, this article stresses, on the one hand, how standards of work became a subject of international and national control and, on the other, how a normative model of "work" arose.

Keywords: International Labour Organization (ILO); Poland; Czechoslovakia; labor standards; social insurances; work
\end{abstract}

DOI: $10.14712 / 23363231.2017 .16$

\section{Introduction}

The Treaty of Versailles established not only a new territorial order, but, with the League of Nations, also a supranational organization charged with maintaining

Apl. Prof. Dr. Natali Stegmann is Professor of East European History at Universität Regensburg. Address correspondence to Lehrstuhl für Geschichte Südost- und Osteuropas, Universität Regensburg, D-93053 Regensburg. E-mail: Natali.Stegmann@geschichte.uni-regensburg.de. The author expresses her thanks to Heike Karge, Katrin Steffen, Luminita Gatejel and two anonymous reviewers for their thoughtful comments on an earlier draft of this article. 
lasting peace. Peace was to be assured in two main ways. The first of these was shared conflict management between nations; to a certain degree, each country was required to give up complete sovereignty and subordinate its home affairs to the ideas and directives of an umbrella organization. ${ }^{1}$ The second aim was the establishment, internally, of what at the time was understood as "social peace."

The countries of East Central Europe were deeply affected both by the redrawing of the continental map and by the idea of social peace. The new, or rather, re-established nation-states of Poland and Czechoslovakia were built from territories that had belonged to the now fallen Russian, German and Habsburg empires. Poland and Czechoslovakia gained not only their own state territories but were also bequeathed a highly heterogeneous institutional and social landscape. ${ }^{2}$ In the Czech lands, Slovakia and the former German and Austrian areas of Poland, the institutions included the beginnings of social insurance schemes. ${ }^{3}$

The International Labour Organization (ILO), ${ }^{4}$ a branch of the League of Nations, was expressly concerned with establishing social peace. While some research on the work of the League of Nations and its branches has been done in recent years (including examination of their impact on non-European countries), ${ }^{5}$ we know almost nothing about how the East Central European states collaborated with the ILO and what effect such collaboration had on the region. This applies to South-East and Eastern Europe as well, and suggests not only a gap in research, but, I would argue, also a blind spot that holds back our understanding of the legacy of social policy-making in Europe as a whole.

Because of national bias in historical studies written about the East Central European region, the impact of international collaboration has been largely

1 Jay Winter, "Imagining Peace in Twentieth Century Europe," Contemporary European History 17, No. 3 (August 2008): 413-22, doi: 10.1017/S0960777308004554.

2 Sascha O. Becker et al., The Empire is Dead, Long Live the Empire! Values and Human Interactions 90 Years after the Fall of the Habsburg Empire (Regensburg: Osteuropa-Institut, 2010).

3 Béla Tomka, Welfare in East and West. Hungarian Social Security in an International Comparison, 1918-1990 (Berlin: Akademie Verlag, 2004), 63-84; Tomasz Inglot, Welfare States in East Central Europe, 1919-2004 (Cambridge: Cambridge University Press, 2008), 54-118. There were important personal and cognitive dimensions to what was inherited from the former imperial powers, but, for practical and analytical reasons, this article restricts its focus to institutions. Russian thinking is excluded from the discussion because, institutionally, Russian legislation on social insurance was only in its infancy before World War I.

4 International Labour Organization is the ILO's official name and spelling.

5 Magaly Rodríguez García, "Conclusion: The ILO's Impact on the World," in ILO Histories: Essays on the International Labour Organization and Its Impact on the World during the Twentieth Century, ed. Jasmien Van Daele et al. (Frankfurt: Peter Lang, 2010), 461-77, here 461-62. 
neglected, both in political history and in the politics of memory. This finding corresponds with Sandrine Kotts's statement that pan-European social policy-making in the interwar period became "invisible" in the 1920s and 1930s after the "nationalization" of discourse in the context of economic crises and the spread of dictatorship. ${ }^{6}$ In her discussion of the construction of a "European social model," Kott mentions Czechoslovakia's active contributions to the ILO as well as a conflict with Poland concerning the administration of health insurance in the early 1930s. ${ }^{7}$ However, she does not reflect upon the impact that the social policies and institutions of the Austrian, German and Russian predecessor states had on those newly founded nations. When writing about Germany's attempt to regain international influence in the 1920 s by showing itself to be an "advanced" country with an "excellent" social policy, Kott refers to the German social model as an "imperial" project. Even though she quotes Czechoslovak sources, which presented Czechoslovak politics as progressive and exemplary, she says little about the Habsburg legislation inherited by Slovakia and the Czech lands. ${ }^{8}$ It is precisely because of their former inclusion in larger states that Poland and Czechoslovakia did not belong to the group "Europe B," whose members were, in the view of the ILO, less-developed European countries, which had to catch up to acceptable social standards. ${ }^{9}$

At the time both states were established and the ILO was founded, Poland and Czechoslovakia already had certain social insurance institutions. They went on to create their post-war policies on that foundation. To understand this as simply the outcome of German influence and domination misconstrues the true phenomenon, as I hope to show in the following discussion. The East Central European countries were not fully "European," if that means being a powerful nation state, perhaps with some colonial dependencies attached, like some of the Western European countries. However, neither were those countries defined by the subordination, exploitation and allegations of "uncivilized" that were applied

6 Sandrine Kott, "Constructing a European Social Model: The Fight for Social Insurance in the Interwar Period," in ILO Histories. Essays on the International Labour Organization and Its Impact on the World during the Twentieth Century, ed. Jasmien Van Daele et al. (Frankfurt: Peter Lang, 2010), 173-95, here 174.

7 Ibid., 183-84, 193; concerning Czechoslovakia, see also Jakub Rákosník, Igor Tomeš et al., Sociální stát v Československu. Právně-institucionální vývoj v letech 1918-1992 (Praha: Auditorium, 2012), 86.

8 Kott, "Constructing a European Social Model," 183-84, 187; on Germany's commitment to the ILO, see also Sandrine Kott, "Dynamiques de l'internationalisation: l'Allemagne et l'Organisation internationale du travail (1919-1940)," Critique internationale 52, No. 3 (2011): 69-84, doi: $10.3917 /$ crii.052.0009.

9 Kott, “Constructing a European Social Model," 190. 
to most non-European, non-Western lands at the time. Rather, the East Central European countries had distinct national traditions, forged in the context of shared imperial statehood and international conflicts. In their philosophical, technological and institutional traditions, they came within the sphere of European culture. What was special about them was that their foundation coincided with the establishment of the post-Versailles international order and that they were part and parcel of this new dispensation of power.

This history is important when we consider the heritage of social policy-making in Poland and Czechoslovakia. While recent research treats social policies above all as a matter of national institutions, ${ }^{10}$ such institutions developed in the East Central European states under the strong influence of two supranational factors: a shared inheritance of pre-existing social insurance systems, and allegiance to the Versailles order, where the ideal of social peace was prominent. The coincidence of institutional continuity and international collaboration was very specific to the region, and getting to grips with that situation can help us understand supranational and European developments better: it gives us a tool to understand social policy-making beyond national politics. Poland and Czechoslovakia are perfect examples to illustrate this process, since both countries were bequeathed social institutions from their former empires, even if conditions thereafter differed in detail (which provides an opportunity for exciting comparisons). The time frame of this study begins with the state founding processes from 1918 to the mid-1920s, when most labor standards and social insurance schemes were enacted in the region. In the case of Poland, I touch upon the 1926 Piłsudski coup d'état. This was a turning point in how social policy-making by the former governments was presented to the people, and is especially noticeable in the texts written for the occasion of the tenth anniversary of the founding of the new nation states and of the ILO in 1928.

Against this general background, the present article explores the collaboration of the Polish and Czechoslovak states with the ILO and their support for the ideal of social peace. The article is based on analyses published in the Sociální revue (Social Revue), the journal of the Czechoslovak Ministry of Social Welfare, and Praca i Opieka Spoteczna (Labor and Social Welfare), the journal of the Polish Ministry of Labor and Social Welfare, along with parliamentary speeches, legislative texts and several brochures produced by the ministries. Additionally,

${ }^{10}$ Monika Eigmüller and Nikola Tietze, A "Socio-histoire" of Europeanization: Perspectives for a Diachronic Comparison, SEU Working Papers 8 (August 2014), 2, https://www.uni-flensburg .de/fileadmin/content/seminare/soziologie/dokumente/working-paper-series/seu-working -paper-8-2014.pdf. 
I studied the files of the Correspondence Office of the ILO in Warsaw as well as the first volumes of the official journal of the ILO, which were published in a range of languages. ${ }^{11}$

This article aims to show social policy-making at the intersection of the founding of state institutions and of international and national processes. Although at first glance Poland and Czechoslovakia seem linked by similarities resulting from previous "foreign rule," national movements and the achievement of statehood following World War I, this article will trace the divergent institutional and political developments in the two countries. At the institutional level, they differed in one key respect: the rebuilt Polish state consisted of areas ceded by several states with a diverse institutional heritage, while the Czechoslovak state was built on territories that had all belonged to the Habsburg Empire and thus benefited from institutional continuity that provided productive ground for international collaboration. ${ }^{12}$ The Czechoslovak state consisted of Slovakia and the formally autonomous Subcarpathian Ruthenia on the one hand and the Czech lands on the other. Until 1918 the formerly mentioned territories were under Hungarian rule and the latter under Austrian control. Their legislative systems were not identical, but they were similar, which of course had a very beneficial effect on the establishment of a unified scheme of social welfare in post-war Czechoslovakia. ${ }^{13}$ The Polish case was different. The "reborn" Polish Republic was built on territories held by the partition powers, Russia, Prussia (after 1871, the German Reich) and Austria (after 1867, the Austro-Hungarian Empire). Social policy legislation in all three areas differed substantially before independence, a fact that was to have severe consequences for the newly founded post-WWI state of Poland.

The following section examines how the ILO's ideal of social peace was addressed by the two new countries. It surveys the conditions of their national politics and the degree of their international collaboration. In the next section, the article traces the engagement of Polish and Czechoslovak policy-makers with the ILO. It takes as an example the implementation of international

11 I used the German version, Amtliche Mitteilungen / Internationales Arbeitsamt. The English version appeared under the title Official Organ / ILO, and the French one under the title Bulletin officiel / Bureau International du Travail.

12 Jakub Rákosník, "Kontinuita a diskontinuita vývoje sociálního státu v Československu (19181956)," Soudobé dějiny 20, No. 1-2 (2013): 21-26; Rákosník, Tomeš et al., Sociální stát, 95; Milan Hlavačka et al., Sociální myšlení a sociální praxe v Českých zemích, 1781-1939 (Praha: Historický ústav, 2015), 203-10; Ludovít Hallon, "Pod ochranou zákonov. Sociálne zabezpečenie v medzivojnovom období,” História 3, No. 6 (2003): 24.

13 Rákosník, Tomeš et al., Sociální stát, 95. 
standards concerning workplace safety and workers' rights, and focuses on the work of the ILO's Correspondence Offices in Warsaw and Prague. Furthermore, the article sketches the development of the Polish and Czechoslovak social insurance schemes and shows how a particular concept of "work" became standard in both countries.

\section{The ILO and Social Peace}

Whether the constructive or the destructive elements in European relations predominated or not during the interwar period is a topic of controversy. Earlier research stressed the destructiveness of policies in that epoch, arguing that the Versailles settlement left a lot of unresolved problems, for example, the status of national minorities, ${ }^{14}$ the radicalization of left- and right-wing parties, ${ }^{15}$ and the brutalization of populations by war and civil war experiences. ${ }^{16}$ More recent publications insist on the constructive aspects of the period. They praise the supranational idea and see the League of Nations as the precursor of the United Nations. They show how the architects of the interwar order accepted basic principles that prepared the ground for long-lasting peace in Europe after World War II. ${ }^{17}$

14 Tara Zahra, “The 'Minority Problem' and National Classification in French and Czechoslovak Borderlands," Contemporary European History 17, No. 2 (2008): 137-65, here 144, doi: 10.1017/ S0960777308004359; Pablo de Azcárte, League of Nations and National Minorities (Washington, DC: Carnegie Endowment for International Peace, 1945), 92-130; Richard Veatch, "Minorities and the League of Nations," in The League of Nations in Retrospect: Proceedings of the Symposium organized by the United Nations Library and the Graduate Institute of International Studies, Geneva, 6-9 November 1980, ed. United Nations Library (Berlin: de Gruyter, 1983), 369-83; Christoph Gütermann, Das Minderheitenschutzverfahren des Völkerbunds (Berlin: Duncker und Humblot, 1979).

15 Jost Dülffer, "Der Niedergang Europas im Zeichen der Gewalt: das 20. Jahrhundert," in "Europäische Geschichte" als historiographisches Problem, ed. Heinz Duchhardt and Andreas Kunz (Mainz: von Zabern, 1997), 105-27; Timothy Snyder, Bloodlands. Europe between Hitler and Stalin (New York: Basic Books, 2010); Dietrich Beyrau, Schlachtfeld der Diktatoren. Osteuropa im Schatten von Hitler und Stalin (Göttingen: Vandenhoeck und Ruprecht, 2000).

16 George L. Mosse, Fallen Soldiers. Reshaping the Memory of the World Wars (Oxford: Oxford University Press, 1990); Wolfgang Schivelbusch, Die Kultur der Niederlage: Der amerikanische Süden 1865, Frankreich 1871, Deutschland 1918 (Frankfurt am Main: Fischer, 2007).

17 Zara Steiner, The Lights that Failed: European International History 1919-1933 (Oxford: Oxford University Press, 2005); Patricia Clavin, "Europe and the League of Nations," in Twisted Paths: Europe 1914-1945, ed. Robert Gerwarth (Oxford: Oxford University Press, 2007), 325-54; Margaret McMillan, Peacekeepers. Six Months that Changed the World (London: John Murray, 2003); John Horne, “The European Moment between the Two World Wars (1924-1933)," in Moderniteit. Modernisme en massacultuur in Nederland 1914-1940, ed. Madelon de Keizer and Sophie Tates (Zutphen: Walburg Pers, 2004), 223-40. 
Above all, the Versailles order offered the East Central European countries an opportunity for the realization of democratic national statehood. Their national fates were highly dependent on the stability of the post-war international security system. The new states of Poland and Czechoslovakia were therefore a product not only of their own national ambitions and traditions, but also of the new order arising after Versailles and their founding fathers' success in persuading the Entente to support their desires for nationhood. ${ }^{18}$ Institutionally, of course, these nations were also a product of the former order that had essentially imposed "foreign rule" upon them. In the growing field of research on internationalism and international organizations, ${ }^{19}$ Poland and Czechoslovakia provide fascinating examples of the interdependence between national and international policy-making, as national ambitions and international encounters mirrored each other perfectly in the process of building the new nation-states after World War I. The war was clearly the catalyst for each state achieving independence. In the case of Czechoslovakia, the extent of its territory was peacefully negotiated at Versailles and with the help of the League of Nations..$^{20}$ Poland, by contrast, fought with the Bolsheviks over territory in the East right up until 1921, when the Treaty of Riga was signed. Because of this, the founding myths of the Polish republic were very much grounded in the border war, which encouraged an additional commitment to the Versailles order. ${ }^{21}$

The peacemakers at Versailles believed that good social policy was a basic prerequisite for a lasting peace. In the ILO, they created a supranational institution concerned with labor issues. The ILO did not operate in competition with national social institutions, but functioned in a way that complemented them,

18 Halina Parafinowicz, "Restoration of Poland and Czechoslovakia in Woodrow Wilson's Policy: The Myth and Reality," in From Theodore Roosevelt to FDR: Internationalism and Isolationism in American Foreign Policy, ed. Daniela Rossini (Keele: Ryburn, 1995), 55-67.

19 Glenda Sluga and Patricia Clavin, eds., Internationalisms: A Twentieth-Century History (Cambridge: Cambridge University Press, 2017); Sandrine Kott, "International Organizations - A Field of Research for a Global History," Zeithistorische Forschungen / Studies in Contemporary History 8 (2011): 446-50; Madeleine Herren, Internationale Organisationen seit 1865. Eine Globalgeschichte der internationalen Ordnung (Darmstadt: Wissenschaftliche Buchgesellschaft, 2009).

20 Jan Karski, The Great Powers and Poland. From Versailles to Yalta, 1919-1945 (Lanham: University Press of America, 1985): 31-46; Josef Kalvoda, The Genesis of Czechoslovakia (New York: Boulder, 1986); Antonín Klimek, Řijen 1918. Vznik Československa (Praha: Paseka, 1998); Zdeněk Kárník, České zeměv ére První republiky I: Vznik, budování a zlatá léta republiky, 1918-1929 (Praha: Libri, 2003).

${ }^{21}$ Karski, Great Powers, 47-75; Jerzy Borzęcki, The Soviet-Polish Peace of 1921 and the Creation of Interwar Europe (New Haven, CT: Yale University Press, 2008); Stanisław Jaczyński, "Generalicja obu walczących stron. Próba charakterystyki i oceny," in Rok 1920: Z perspektywy osiemdziesięciolecia, ed. Andrzej Ajnenkiel (Warszawa: Instytut Historii PAN, 2001), 25-36. 
which hints at the entanglement of national and international thinking in the context of modern social policy. ${ }^{22}$ The Peace Treaty itself mentioned the interconnection between social justice and peacekeeping. The rationale for establishing the ILO was set out in Part XIII of the treaty:

Whereas the League of Nations has for its object the establishment of universal peace, and such a peace can be established only if it is based upon social justice; And whereas conditions of labor exist involving such injustice, hardship, and privation to large numbers of people as to produce unrest so great that the peace and harmony of the world are imperiled; and an improvement of those conditions is urgently required [...] Whereas also the failure of any nation to adopt humane conditions of labor is an obstacle in the way of other nations which desire to improve the conditions in their own countries; The High Contracting Parties, moved by sentiments of justice and humanity as well as by the desire to secure the permanent peace of the world, agree to the following: $[\ldots] . .^{23}$

The Versailles Treaty stipulated the implementation of international labor standards. Its framers strongly believed that reduction of social dissatisfaction was a major task in the job of achieving "peace and harmony in the world." Universal justice and humanity were to be realized through modern social policy-making. Responding to this call, the member states sent delegates to the ILO, who included not only governmental officials, but also representatives of social movements and an array of experts. Trade unions and employers from every single nation each sent an equal number of representatives as well (in so-called tripartism, along with the governmental delegates). ${ }^{24}$ The ILO came up with very concrete measures to be implemented within its member states. Recent historical research considers the ILO as an agency for generating knowledge (an epistemic community), as an international bureaucracy, and as a network of politicians, social activists, specialists, and employers engaged in the field nationally and internationally, who together created a certain "ILO spirit." The ILO was a place for negotiating social rights on an international scale, reflecting national

22 Glenda Sluga, Internationalism in the Age of Nationalism (Philadelphia: Philadelphia University Press, 2013), 3.

23 The Versailles Treaty, June 28, 1919, Part XIII - Preamble, The Avalon Project. Documents in Law, History and Diplomacy, Yale Law School, http://avalon.law.yale.edu/imt/partxiii.asp.

${ }^{24}$ Jasmien Van Daele, "Writing ILO Histories: A State of the Art," in ILO Histories. Essays on the International Labour Organization and Its Impact on the World during the Twentieth Century, ed. Jasmien Van Daele et al. (Frankfurt: Peter Lang, 2010), 13. 
developments onto international stages and vice versa. In that respect, twentieth century social policy-making clearly had an international component. ${ }^{25}$ Before I give examples of that, I will show the different imprints the ILO's leading ideas left on Poland and Czechoslovakia.

\section{Conditions of National Politics and Institutional Collaboration}

The founders of the ILO began their work with great enthusiasm. Well aware of the utopian nature of an international organization dedicated to social justice, they shared a common belief in the need to create a permanent worldwide system of peace and social security, built on the principles of justice and redistribution. ${ }^{26}$ In their opinion, the fair distribution of social goods would legitimize the modern democratic order at both the national and international levels. On the occasion of the tenth anniversary of the ILO, a celebratory publication referred to the "masses" whose dreams and needs "lay behind the initiatives of the statesmen":

Without doubt, the people's desire for peace - the great dream of international reconciliation and social justice that they cherished throughout the dark days of war lay behind those statesmen's initiatives. Without that unanimous spirit, which existed at the deepest levels in each country, there would have been no Peace Conference, no mandating Commission for the League of Nations and no Commission on International Labour Legislation. But the masses found it difficult to recognize things they had been striving for in the often complex legal texts that were presented to them. ${ }^{27}$

By the time of the ILO's tenth anniversary, Poland was still a member, but no longer was a democratic state. After the Piłsudski coup in 1926, Poland was led by an authoritarian regime with no clear ideological worldview. What had happened to the "masses" and the progressive "statesmen" there? Following the reestablishment of the Polish state in 1918, the country's constituent assembly decided to unify the different legislative bodies from the former partitioned areas, and the standard of social insurance maintained in the German and

25 Sandrine Kott and Joël Droux, "Introduction: A Global History Written from the ILO," in Globalizing Social Rights. The International Labour Organization and Beyond, ed. Sandrine Kott and Joël Droux (Basingstoke: Palgrave, 2013), 1-14.

${ }^{26}$ Dix ans d'organisation internationale du travail, ed. Bureau International du Travail (Genève, 1931): 21, 39 .

27 Ibid, 2. 
Austrian regions was extended to the larger but poorer former Russian zone. This precipitated new laws on health insurance (1920), pensions for invalid veterans (1921), social welfare (1923) and general age and disability pensions (1929). ${ }^{28}$ A lack of precursor institutions in several areas, coupled with a dearth of other resources, hampered the uniform application of these laws. Therefore, the process of setting up a full social insurance system lasted for decades, and local institutions achieved very different results.

The Piłsudski coup has been explained as the result of people's frustrations with the parliamentary system in Poland and by the extreme difficulties it had in creating a modern state attuned to the ideas of the time. ${ }^{29}$ This does not mean that politicians ceased to care about improving people's social well-being, or that Poland gave up its engagement with the Versailles order. Studies of the contemporary social policy in Poland do not regard the coup as a disruption of progress in that regard. Several initiatives were kept going, especially the provision of social insurance. ${ }^{30}$ Institutionally, the Piłsudski government had to face inherited problems. It continued the policies of the democratic governments that had preceded it. In a way, it was even more effective, because ministers could act without consulting the Polish parliament, the Sejm. Politically, however, the Piłsudski regime insisted on national traditions and étatisme, on heroism, and on the personal leadership of Józef Piłsudski (1867-1935) as the defender of Polish interests. ${ }^{31}$ This meant that the Piłsudski government's commitment to the Versailles order was ambivalent. It strongly emphasized national interests above international ties and used ideals of social justice as a way of wooing the "masses." 32 In the early years, too, the scarce resources of the Polish state were absorbed by an exhaustive border war. Ideologically (especially after 1926), the border war was the most important point of reference.

28 Bénédicte Zimmermann, Arbeitslosigkeit in Deutschland. Zur Entstehung einer sozialen Kategorie (Frankfurt am Main: Campus, 2006).

29 Janusz Żarnowski, “Rola państwa w kszałtowaniu społeczeństwa Polski międzywojennej: Zarys problemu i uwagi wstępne," in Metamorfozy społeczne, ed. Janusz Żarnowski, vol. 8, Państwo i społeczeństwo Drugiej Rzeczypospolitej (Warszawa: Instytut Historii PAN, 2014), 19-21.

30 Paweł Grata, Polityka społeczna Drugiej Rzeczypospolitej. Uwarunkowania - instytucje - działania (Rzeszów: Uniwersytet Rzeszowski, 2013).

${ }^{31}$ Peter Hetherington, Unvanquished. Joseph Pilsudski, Resurrected Poland, and the Struggle for Eastern Europe (Houston, TX: Pingora Press, 2012).

32 The most controversial issue was the agreement on the protection of minorities, which was seen by the Polish government as a diktat brought back to the country by Roman Dmowski, the Polish signatory of the Versailles Treaty. The agreement was canceled by the Polish government in 1934; see Paweł Korzec, "Polen und der Minderheitenschutzvertrag (1919-1934)," Jahrbücher für Geschichte Osteuropas 22, No. 4 (1974): 515-55. 
This helps explain the low recognition given by Poles to its representatives in international politics. The most important politician working in this sphere was Franciszek Sokal (1881-1932). An engineer by training and a liberal democrat, he was one of the Polish delegation members at the Versailles Conference, along with Piłsudski's political rival Roman Dmowski and others. From 1918, he was head of the Department of Occupational Safety (Sekcja Obrony Pracy) and chief inspector at the newly established Ministry of Labor and Social Welfare. He became head of this ministry in the Grabski government (1924-1925). ${ }^{33}$

Sokal represented Poland at several conferences of the ILO and published a booklet in Polish about the organization in $1920 .{ }^{34}$ In 1925 he authored a brochure on the state of Polish social policy, which appeared in English and French versions. ${ }^{35}$ He wrote a series of articles for the journal Praca i Opieka Spotecz$n a$ on international social policy. Thus, he was clearly an important propagator of the cause of social peace. However, apart from an entry in Polski Stownik Biograficzny (the Polish Dictionary of National Biography), no recent research has been done on him and his engagement in the field.

When Sokal died in 1932 in Bern, Switzerland, Praca i Opieka Spoteczna ran an obituary. The journal listed all his posts, mentioning that he had held a mandate at the administrative council of the ILO since 1920 and had only returned to Poland to carry out his duties as a minister. The journal acknowledged his experience in the work of international institutions, including the ILO, underlining his strong belief in social justice. It also hailed him as a patriot, who always upheld the interests of his homeland in the international arena. ${ }^{36}$ Sokal dedicated his life to the ILO, but he did not gain much recognition, either during his lifetime or posthumously. He was something of an outsider on the Polish political scene.

In complete contrast, Czechoslovak politicians who engaged in supranational affairs were lauded at home. Their work was seen as consolidating the so-called "revolution from abroad" that had created the new Czechoslovak state

${ }^{33}$ Henryk Korczyk, "Franciszek Sokal," in Polski Stownik Biograficzny, vol. 40 (Warszawa: Instytut Historii PAN, 2000-2001), 15-18.

${ }^{34}$ Franciszek Sokal, Komisja pracy Konferencji Pokojowej w Paryżu 1919 r. (Warszawa: Wydawnictwo Ministerstwa Pracy i Opieki Społecznej, 1920).

35 Franciszek Sokal, Social Insurance in Poland (Geneva: Albert Kundig, 1925); François Sokal, Les Assurances Sociales en Pologne (Warsaw: Le Ministère du Travail et de l'Assistance Sociale de la République de Pologne, 1925).

36 "Die Beziehungen der Republik Polen zum Internationalen Arbeitsamt," Amtliche Mitteilungen / Internationales Arbeitsamt 5 (1922), 284-85; "Franciszek Sokal," Praca i Opieka Spoteczna 12 (1932): 58-59. 
by diplomatic action. ${ }^{37}$ In many aspects, Czechoslovak social and international policy followed traditional paths. Almost all the Czechoslovak territories already had an institutionalized social policy, which made the situation much easier than in the Polish case. In the Czech and Slovak lands, health and disability insurance, along with disability pensions, had been enacted during the time of Habsburg rule. After the founding of the new state, this safety net needed only to be improved and extended to other forms of social insurance.

In addition, most prominent Czechoslovak politicians had served the Habsburg Empire. They were politically experienced and often highly educated, whereas in Poland, politicians from the former Austrian territories did not have the same reputation. The economic situation was much better in Czechoslovakia than it was in Poland, ${ }^{38}$ and the political situation was marked by stability. ${ }^{39}$ This stability was particularly due to the engagement of the state's founders, Tomáš G. Masaryk (1850-1937) and Edvard Beneš (1884-1948). Both had been professors in the pre-war period, Masaryk as a philosopher and Beneš as a sociologist, and Masaryk had been engaged in politics since the 1880s. Both men had pressed hard for a Czechoslovak nation-state at the Paris Peace Conference. Together with the Slovak Milan Rastislav Štefánik (1850-1919), they started a campaign to free the Czech lands and Slovakia from the Habsburg Empire.

In late 1918, with help from the "Czechoslovak Legion," 40 this led to the foundation of the Czechoslovak state under the protection of the Entente.

37 Zbyněk Zeman, Der Zusammenbruch des Habsburgerreiches, 1914-1918 (München: Oldenbourg, 1963), 230-40; Kárník, České země, 19-33; Dušan Kováč, "1918: Začiatok, alebo koniec? Dva transformačné modely v strednej Európe," in 1918: Model komplexního transformačního procesu, ed. Lucie Kostrbová, Jana Malínská et al. (Praha: Masarykův ústav a Archiv AV ČR, 2010), 11-20; Maciej Górny, “Národ a revoluce. Rok 1918 v kontextu 'pokrokových tradic' národních dějin ve středovýchodní Evropě,” in 1918: Model komplexního transformačního procesu, ed. Lucie Kostrbová, Jana Malínská et al. (Praha: Masarykův ústav a Archiv AV ČR, 2010), 51-62.

38 David F. Good, "The State and Economic Development in Central and Eastern Europe," in Nation, State and the Economy in History, ed. Alice Teichova and Herbert Matis (Cambridge: Cambridge University Press, 2003), 133-58; Uwe Müller, "Regionale Wirtschafts- und Nationalitätenpolitik in Ostmitteleuropa (1867-1939)," in Ausgebeutet oder alimentiert? Regionale Wirtschaftspolitik und nationale Minderheiten in Ostmitteleuropa (1867-1939), ed. Uwe Müller (Berlin: Berliner Wissenschaftsverlag, 2006): 9-57; Cecylia Leszczyńska and Łucja Lisiecka, "Polish Lands before and after the First World War, Effects of Breaking the Economic Ties with Germany, Austria and Russia for the Polish Regions," Studia Historiae Oeconomicae 25 (2005): 11-26.

39 Andrea Orzoff, Battle for the Castle. The Myth of Czechoslovakia in Europe, 1914-1948 (Oxford: Oxford University Press, 2009); Kárník, České země, 137-69; Eva Broklová, Prezident Republiky československé. Instituce a osobnost T. G. Masaryka (Praha: Masarykův ústav AV ČR, 2001).

${ }^{40}$ Gerburg Thunig-Nittner, Die tschechoslowakische Legion in Rußland: ihre Geschichte und Bedeutung bei der Entstehung der 1. Tschechoslowakischen Republik (Wiesbaden: Harrassowitz, 1970); Jan Galandauer, “Československé legie a jejich komemorace," in Česká společnost za velkých 
Masaryk became the country's first president and Beneš its first minister of foreign affairs. When Masaryk gave up the presidency in 1935, Beneš became his successor. Both embodied the founding myth of the "revolution from abroad," close political and ideological relationships with the Versailles order and the founding of the Czechoslovak state itself. When Beneš became president of the seventh session of the ILO (1925-1926), he pointed all this out in his introductory speech to the organization. ${ }^{41}$

Social policies were highly relevant to the legitimation of the new Czechoslovak democratic order, since fair social distribution had been a constant selling point for citizens during the transfer from Habsburg rule. Institutionally and ideologically, social policy provided a strong link between the government and the citizens and between the old and new political systems. ${ }^{42}$ Czechoslovakia was therefore very much committed to the ILO, which to a substantial degree was the result of the fact that the country shared the heritage of enlightened Habsburg social politics. Czechoslovakia's collaboration with the ILO was as much a continuation of late nineteenth century and early twentieth century leftist (or worker advocates') internationalism, as it was the result of close national-international epistemic encounters in social policy-making during the interwar period. The only monograph on the topic, published in 1928, so contends. ${ }^{43}$ Continuity in social policy was not the result of "imperial" German (or Austrian) domination, but of path-dependency. This was especially true of Czechoslovak activists on the issues.

To demonstrate that Czechoslovakia's ideological commitment to the ILO was based on personal continuities, let me show how the topic was presented in Sociální revue when Beneš took over the Czechoslovak presidency. Several articles dealt with Masaryk's legacy in social policy-his engagement in the early post-war years, his philosophical thinking on the topic, his political approach to

válek 20. století (pokus o komparaci), ed. Jan Gebhart (Praha: Karolinum, 2003): 293-312; Ivan Šedivý, "Legionáři a mocenské poměry v počátcích ČSR", in Moc, vliv a autorita v procesu utváření meziválečné ČSR (1918-1921), ed. Jan Hájek et al. (Praha: Masarykův ústav a Archiv AV ČR, 2008), 16-28.

41 "Zahajovací řeč předsedy VII. mezinárodní konference práce min. zahraničních věcí dra Beneše," Sociální revue 6 (1925): 161-65.

42 Natali Stegmann, Kriegsdeutungen - Staatsgründungen - Sozialpolitik. Der Helden- und Opferdiskurs in der Tschechoslowakei, 1918-1948 (München: Oldenbourg, 2010), 81-85; Kott, "Constructing a European Social Model," 177-78.

43 Josef Skoch, Mezinárodní organisace práce a Československo: Genese mezinárodní organisace práce, její působení a účast Československa na jejím díle (Praha: Sociální ústav Československé republiky, 1928), 166-70. 
social action, and his commitment to the social welfare of youth. ${ }^{44} \mathrm{Lev}$ Winter (1876-1935), who had been engaged in social politics since the turn of the century and who became the first Czechoslovak Minister for Social Welfare (and who held the post again from 1922 to 1926), stressed the great importance the president had attached to protecting the "socially weak" and that the "Czechoslovak republic had become a vivid exemplum of social progress." Winter was a member of the social security committee of the ILO. Thus, when he pointed out that the first statute Masaryk signed after independence was for an eighthour working day, he was linking the presidency to the efforts of the ILO, since the regulation of working hours was a central part of its work at that time. ${ }^{45}$

All the articles in Sociálni revue portrayed Masaryk as the embodiment of building a social state and of justice. Because Beneš had been closely associated with Masaryk's social program, the praise for the older politician also reflected on the younger one, who promised to maintain the record of good social policy-making in the Masaryk tradition. Adherence to the ILO was in harmony with policy-making at home and with the image the founders of the Czechoslovak state wished to project. Especially in the early 1930s, engagement with supranational organizations and commitment to robust social policy was of the highest importance for the Czechoslovaks, who took an active role in international policy-making. At the time of the tenth anniversary of the ILO, the country intensified its commitment.

\section{Meeting International Standards: Correspondence Offices and Standards for the Workplace}

What did all this mean for concrete policy-making at home? Let us begin with workplace standards, an issue which absorbed a lot of institutional resources. A great many of the articles in the official journal of the ILO, and also in the publications of the Polish and Czechoslovak ministries, dealt with the progress of implementing standards in the member states. The ILO's contribution was the immense collection and exchange of information, all very precise, down-to-earth

${ }^{44}$ Lev Winter, "Styk presidenta Masaryka s Ministerstvem sociální péče v prvních letech poválečných," Sociální revue 16 (1935): 69-70; Evžen Štern, "Masarykova sociální škola," Sociální revue 16 (1935): 71-80; Otakar Sulík, "Masaryk a úkoly sociální správy," Sociální revue 16 (1935): 81-86; Kamil Šlák, "Péče o mládež v díle Masarykově," Sociální revue 16 (1935): 87-92.

45 Winter, "Styk presidenta Masaryka"; Jakub Rákosník, "Lev Winter (1876-1935) - Architekt der tschechoslowakischen Sozialpolitik," in Sozial-reformatorisches Denken in den böhmischen Ländern 1848-1914, ed. Lukáš Fasora et al. (München: Martin Meidenbauer, 2010), 236; Aug. Žalud, “Dr. Lev Winter (1876 - 26. ledna - 1926),” Sociální revue 7 (1926): 22-31. 
and professional. Unavoidably, vast masses of material were produced and accumulated, frequently regurgitating one and the same issue in different forms and languages. As the organization had (theoretically) worldwide authority, this reduplication seems to be simply a sign of boring administration. The material is rather technical, aimed at giving information to professionals and politicians who had the task of putting the ILO's directives into effect. Hence there is considerable duplication in the different archival sources. ${ }^{46}$

Most of the documents from the Correspondence Office of the ILO in Warsaw reflect the content of the ILO's and the national journals. The Correspondence Office was in fact the place where the material was created. In Warsaw, it was Adam Rose (1895-1951) who managed this huge quantity of work from the opening of the Office in 1922 up to the year 1929. Rose had studied at the Agrarian Academy in Berlin and the Economics Faculty in Jena before he was appointed to his Warsaw post. Between 1922 and 1929 he was also an official of the Ministry of Agriculture (Ministerstwo Rolnictwa i Reform Rolnych). In 1929 , he was the main expert behind the agrarian reform of that year, and from 1930 he served as the director who implemented it. Most of his writings were about agrarian issues. ${ }^{47}$ In his post at the local ILO office, Rose received a mass of questionnaires from Geneva, inquiring about the state of working conditions in different sectors. To answer them, Rose corresponded with a range of people and institutions in Poland, among them libraries, the offices of labor movements, deputies at the Sejm, the government's Statistical Office, and professional organizations, requesting specific pieces of information and statistics. Some of this information subsequently appeared in his contributions to the ILO's official journal. Rose also championed the ILO's work in the Polish press, occasionally, along with Sokal, reacting to statements it had published. 48

The impression one gets from this correspondence is ambiguous. On the one hand, the material reveals the networks behind the work of the ILO, connecting the Head Office in Geneva with the local ILO office in Warsaw, and extending out to specialists, social movements and administrative institutions at both the national and international levels. Hence, the organization was successful in bringing information together. On the other hand, if we look at the Correspondence Office's files alongside the publications of the institutional bodies, it seems

46 Kott, "Constructing a European Social Model," 182-83.

47 Zbigniew Landau, "Rose, Adam Karol,” in Polski Stownik Biograficzny, vol. 32 (Wrocław/ Warszawa/Kraków: PAN, 2000-2001), 41-43.

48 Oddział Korespondencyjny w Warszawie, Biuro Korespondencyjne 1922-1939, 1945-1950, Syg. 1-8. Zespół 26: Międzynarodowe Biuro Pracy, Archiwum Akt Nowych, Warszawa. 
to have been consumed by administrative work. As for data, the files do not contain much more than what was already to be found in the official publications of the institutions it dealt with.

The similar character of the sources allows us to conclude that the ILO Correspondence Office in Prague, led by Evžen Štern (1889-1942), functioned in much the same way as the one in Warsaw. ${ }^{49}$ Štern, who had studied law in Prague and in Paris, was a social democrat and a supporter of Masaryk. He became one of the creators of the social insurance scheme in Czechoslovakia and was especially concerned with the problem of unemployment. ${ }^{50}$

The idea that work is a moral good was promulgated at the ILO conference in Washington in 1919 and in subsequent conferences. The member states formulated a list of labor standards which were stated to be universal and which national parliaments were required to enact into law. The most important task of ILOs work in the interwar period was harmonizing and internationalizing standards. This happened against the backdrop of socio-economic perceptions of the interplay between international economic competition and social policy-making. ${ }^{51}$

Among other things, ILO standards regulated hours of work (with the establishment of a maximum working day and week); labor supply; prevention of unemployment; provision of an adequate living wage; protection of workers against sickness, disease and injury arising from their employment; the protection of children, young persons and women; provisions for old age and injury; and protection of the interests of workers when employed in countries other than their own. The ILO defended the principle of freedom of association and endorsed the provision of vocational and technical education. As Pauli Kettunen emphasizes, counting the number of international treaties that were ratified, as was the practice of the ILO, hardly helps to understand the impact of the ILO's activities on national social policy-making. It is essential to follow the implementation of those treaties on the national level, too. ${ }^{52}$

In his brochure about the ILO, written in 1920, Sokal stressed how Poland should implement the ILO's requirements. Though he admitted the difficulty of uniting the country's disparate parts, he saw engagement with the ILO

\footnotetext{
49 "Beziehungen der Tschechoslowakei zum Internationalen Arbeitsamt," Amtliche Mitteilungen / Internationales Arbeitsamt 5 (1922): 175-76.

50 “Štern, Evžen (1889-1942), Sozialpolitiker und Publizist," in Österreichisches Biographisches Lexikon, vol. 60 (Wien: Österreichische Akademie der Wissenschaften, 2008), 224-25.

${ }^{51}$ Pauli Kettunen, "The ILO as a Forum of Developing and Demonstrating a Nordic Model," in Globalizing Social Rights. The International Labour Organization and Beyond, ed. Sandrine Kott and Joël Droux (Basingstoke: Palgrave, 2013), 218-19.

52 Ibid., 218.
} 
as important for the progress of social reform throughout Poland and for the development of its statehood. He declared that his nation had always fought on the side of freedom and progress. ${ }^{53}$ In the years following the Washington Conference, Poland ratified several international conventions. These included conventions on unemployment; on the minimum age in industry; on night work; on night work by young persons; on the minimum age for employment at sea and in agriculture; on the agricultural workers' rights of association; on workmen's compensation in agriculture; on the use of white lead in paints; on weekly rest periods for employees of industrial enterprises; on the minimum age for employment as trimmers or stokers; on compulsory medical examination of children and young persons employed at sea; and on hours of work for tram drivers. ${ }^{54}$

Czechoslovakia was also concerned about labor standards and maintained consistently constructive relations with the ILO. The Ministry of Social Welfare (Ministerstvo sociální péče) regularly reported back to the ILO, and gave details in its own publications about progress in passing relevant bills. By 1929, Czechoslovakia had implemented in legislation 11 out of the 28 international conventions formulated by the ILO. These conventions covered hours of work (limiting them to eight per day); night work by women; the minimum age for employment at sea and in agriculture; night work by young persons; agricultural workers' rights of association; the use of white lead in paints; weekly rest periods for employees of industrial enterprises; the minimum age for employment as trimmers or stokers; compulsory medical examination of children and young persons employed at sea; and weekly hours of work. The remaining 17 conventions were addressed, but had not yet been implemented legally. 55

Of course, the list of treaty ratifications raises a lot of questions concerning their exact content and the national debates that surrounded them and their implementation. The complexity of the topic becomes apparent in the example of the failed ratification of the ILO Hours of Work Convention in Poland. Poland had issued a decree mandating an eight-hour day even before the convocation of the ILO's constituent assembly, ${ }^{56}$ but by 1925 the Sejm had still not implemented the Washington convention on the same subject. As the process

53 Sokal, Komisja Pracy, 15.

54 "Międzynarodowy ustawodawstwo pracy," Praca i Opieka Społeczna 5 (1925): 4-33.

55 Josef Skoch, "Stav ratifikací mezinárodních konvencí pracovních a Československo," Sociální revue 10 (1929): 547-48.

56 “Dekret o 8-mio godzinnym dniu pracy,” Dziennik Praw Państwa Polskiego, No. 42 (1918): 104-105. 
of international standardization came to a halt overall, Adam followed advice from Sokal to send an abstract of a stenographic note from debate in the British House of Commons to a deputy of the Sejm who had publicly brought up the question of whether the eight hour convention should be passed. ${ }^{57}$ The British Minister of Labour, Sir Arthur Steel-Maitland, had expressed his intent to ratify the convention, which implied, as he only explained after being asked, "informal communication" about the readiness of the German and the American governments to do the same. ${ }^{58}$

Indeed, that strategy was not successful; neither Germany nor Great Britain ever ratified the ILO Hours of Work Convention. ${ }^{59}$ In general, ratification could be refused by national Parliaments even though their state representatives had signed a convention and the state already had a national law in accordance with the proposed international standards. Setting of standards, and implementing them into national law, was a complicated process of negotiating the interests of political parties and social partners (the trade unions and the employers). The ILO helped by producing arguments for social policy-making on the national level, even when the ratification of certain international standards failed in the national parliaments. ${ }^{60}$ The example of Polish legislation on hours of work illustrates perfectly how communications from the ILO were woven into national and international policy-making.

As can be seen, the ILO justified its control over labor standards with very moralistic arguments, while the various local champions of the international program had to do all the everyday empirical work. Nevertheless, the national officials managed to enact a lot of the ILO's regulations successfully, and kept their overall faith in social reform. In this respect, there was no difference between Poland and Czechoslovakia in the early interwar years. After 1926, however, Polish collaboration with the ILO did go through something of a change. At a casual glance, the material from the Correspondence Office in Warsaw does not

57 Do Pana Posła Ziemięckiego, 19. września 1925, Oddział Korespondencyjny w Warszawie, Biuro Korespondencyjne 1922-1939, 1945-1950, Syg. 8. Zespół 26: Międzynarodowe Biuro Pracy, Archiwum Akt Nowych, Warszawa. See also Bronisław Ziemięcki, "Czy konwencja o 8-godzinnym dniu pracy będzie ratyfikowana?” Robotnik (1925), 155.

${ }^{58}$ Hours of Labour(Washington Convention), Hansard, June 16, 1925, http://hansard.millbanksystems .com/commons/1925/jun/16/hours-of-labour-washington-convention\#S5CV0185P0_19250616 _HOC_188.

59 Jasmien Van Daele, "Industrial States and Transnational Exchange of Social Polities: Belgium in the Interwar Period," in Globalizing Social Rights. The International Labour Organization and Beyond, ed. Sandrine Kott and Joël Droux (Basingstoke: Palgrave, 2013), 198.

${ }^{60}$ Kettunen, “The ILO as a Forum,” 210. 
show a significant disruption after the Piłsudski coup. On closer inspection, it becomes obvious that correspondence with Geneva decreased. Rose continued to collect material on working conditions in several industrial sectors in Poland, but he was now using his position to promote his own work on the Polish agrarian question. ${ }^{61}$

\section{Social Insurance: Defining “Work”}

As mentioned previously, social insurance policies were built on the institutional heritage from the former rulers of the Polish and Czechoslovak territories, and on international standards. Czechoslovakia was in a more comfortable situation than Poland in the area of inherited institutions and enacted more legislation. In both countries, the formation of a social insurance system contributed to a normative definition of work, regardless of how successful implementation of standards proved to be.

International social policy concentrated on the world of work, which was a natural result of national commitment to the Versailles Treaty and the ILO's engagement on labor standards. In the perception of the times, workers and the labor movement constituted a political power base and, together with the peasantry, embodied the nation itself. The ideal of social peace had this perception as its basis. Hence, work lay at the core of social policy on both the international and national levels. The provision of social insurances was (and still is) affected by institutional inertia, path dependency and the shape of expectations. ${ }^{62}$

When, in 1918-1919, the Versailles order came into being and Poland and Czechoslovakia were (re)established as independent states, national legislation was based on the institutional heritage from the pre-war powers. Those powers had instituted insurance for workplace accidents, and the system favored industrial workers and heads of families. ${ }^{63}$ Definitions in the legislation implied a fixed (and also gendered) idea of what was meant by "worker" and "work," since the insurance scheme was directed at only a limited group.

${ }^{61}$ Oddział Korespondencyjny w Warszawie, Biuro Korespondencyjne 1922-1939, 1945-1950, Syg. 8. Zespół 26: Międzynarodowe Biuro Pracy, Archiwum Akt Nowych, Warszawa.

62 Tomka, Welfare, 18-20; Eigmüller and Tietze, A "Socio-histoire," 2-3; Thomas H. Marshall, "Staatsbürgerrechte und soziale Klassen," in Bürgerrechte und soziale Klasse. Zur Soziologie des Wohlfahrtsstaates, ed. Elmar Rieger (Frankfurt am Main: Campus, 1992), 67, 75.

${ }^{63}$ Erna Appelt, Geschlecht - Staatsbürgerschaft - Nation. Politische Konstruktionen des Geschlechterverhältnisses in Europa (Frankfurt am Main: Campus, 1999), 161. 
When the successor states enacted social insurance measures after the war, this original legislation served as a blueprint for further development. Following the logic of modernization, the same standards had to be extended to the less-developed parts of Poland and to less-developed nations beyond. The ILO established norms for the provision of social benefits throughout Europe, ${ }^{64}$ and a recommendation to launch social insurance schemes was issued at its Washington conference. ${ }^{65}$

The first social insurance initiative after World War I in Poland was health insurance, while in Czechoslovakia it was the inauguration of pensions for the aged (something that was only introduced in Poland after World War II). For the Poles, the establishment of wider health insurance was complicated by the problem of unification. Czechoslovakia benefited from pre-existing laws it could build on and had an already functioning compulsory health insurance system for workers, which covered their family members as well. ${ }^{66}$ It used this health insurance legislation as a blueprint for the implementation of old age pension insurance in 1924. Though the Czechoslovak politicians profited from earlier legislation and institutions, in their rhetoric they extolled the democratic, modernized character of their new state with its "Czechoslovak spirit." The deputies in parliament stressed how democracy and social policy went hand in hand, and how much they were developing the country, making no mention of former models. ${ }^{67}$ This can be seen in the case of old age pension insurance, which was constructed in 1924 according to the principles of the older health insurance law, but which was heralded as a prestige project of the young republic and "proof of the socially-responsible character of Czechoslovakia."68

When Poland was unifying its health insurance system in 1920, the parliamentary deputy Ludwik Waszkiewicz (1888-1976), who was active in the workers' movement in Łódź and (like Sokal) was much involved in the Department for Occupational Safety, ${ }^{69}$ got up to speak in the Sejm. He made one of the rare programmatic statements about social policy in the country. The health insurance the Sejm was enacting, he argued, was a fundamental element in the new political and cultural organization of Poland. In the process of democratization, it was important not only to continue the best social and political legacies of Ger-

\footnotetext{
${ }^{64}$ Kott, "Constructing a European Social Model," 176-95.

65 Dix ans, 177.

${ }^{66}$ Evžen Štern, “Deset let naší sociální politiky," Sociální revue 10 (1929): 16.

${ }^{67}$ Deset let Československé republiky, vol. 3 (Praha: [s.n], 1928), 88-90.

68 Zdeněk Deyl, Sociální vývoj Československa 1918-1938 (Praha: Academia, 1985), 85.

69 Bolesław Pełka, "Ludwik Waszkiewicz," in Archeion 67 (1979): 347-49.
} 
man and Austrian rule, but to improve them and extend them to all areas. Polish citizens - and here he included national minorities - would then appreciate the new state as a defender of their interests. ${ }^{70}$

Paradoxically, it was Czechoslovakia that had more success in winning over its citizens in this way, though improving upon the former legislation was not expressed as a program goal. ${ }^{71}$ Polish politicians were less able to convince their citizens that social goods were being fairly distributed. Among other things, this was because of big regional differences in the implementation of insurance benefits in Poland. In the case of health insurance, the Polish law of May 19, 1920, stipulated compulsory insurance and covered a wide range of employees and their family members. ${ }^{72}$ The former German and Austrian communities, where such cover was already established (as in Czechoslovakia), had existing money in their funds, but the newly established branches in formerly Russian areas needed subsidizing. This meant that a lot of communities, especially in the poorer East, were simply not able to run the system. ${ }^{73}$ Hence, some regions of the country, along with the entire Polish agrarian sector, were excluded from the social insurance system. Inequality was not reduced at all.

Even though the system did not work consistently nationwide, it established who was to be counted in: those who earned regular wages at a workplace, along with their dependent family members. It also established an equitable system whereby workers' payments into the fund depended on size of their wages, whereas payments out to them in case of illness did not, and family members could benefit without any extra payment at all. In this respect, the Polish system did not diverge from the former model and from the practice in Czechoslovakia, Germany, Austria and several other European countries. ${ }^{74}$

The national and international obsession with work took on an even more striking form in the definition of unemployment and the allocation of unemployment insurance benefits. The post-war economies could not provide enough opportunities for everyone to get paid work - a circumstance that was especially

70 Sprawozdanie stenograficzne ze 129 posiedzenia Sejmu Ustawodawczego z dnia 12 marca 1920 r., col. 42, https://bs.sejm.gov.pl/exlibris/aleph/a22_1/apache_media/I83LDEX9QBVNP55 CF97KGKC3B8SKDP.pdf.

${ }^{71}$ Natali Stegmann, "Die Habsburgermonarchie als Fundament: Sozialpolitik in der Tschechoslowakei, 1918-1948," in Staatsbürgerschaft und Teilhabe. Bürgerliche, politische und soziale Rechte in Europa, ed. Kathrin Boeck et al. (München: De Gruyter Oldenbourg, 2015): 51-65.

72 Zofia Daszyńska-Golińska, Ubezpieczenia społeczne (Warszawa: Wolna Wszechnica Polska, 1929), $10-12$.

73 Sokal, Social Insurance, 69.

74 Inglot, Welfare States, 55-57. 
hard on demobilized soldiers - so the ILO was particularly concerned about unemployment rates. This concern was noticeable in the field of statistics. Statistical tracking of social problems, done by the Statistical Branch of the ILO, ${ }^{75}$ assumed great importance. As Bénédicte Zimmermann argues, ILO statistics were based on sets with given definitions and thereby on fixed categories. ${ }^{76}$

The modern idea of unemployment is a product of social welfare discourse and rests on a strict distinction between "proper" employment and non-employment. The non-employed came to be defined either as "unproductive" individuals, dependent on social welfare, or as persons who normally could work "productively" for an employer but who involuntarily suffered from occasional lack of opportunities to work. Only in the latter case was "unemployed" status granted. Both international and national policies between the wars adhered to this way of thinking about the issue and reinforced it in their manner of implementation of their insurance schemes. This is made quite clear in the ILO's unemployment policies. ${ }^{77}$

In Poland in 1923, the Ministry of Labor and Social Welfare (Ministerstwo Pracy i Opieki Społecznej) declared that the "existence and the future of the Polish people" depended on "our work and productivity."78 The government saw itself as the guarantor of social security and believed that politics should respond to the most up-to-date findings of economists. The Polish prime minister, Władysław Sikorski (1881-1943), announced the government's intention to enact a social insurance scheme but insisted that workers' productivity must be shown to justify it and make it possible. ${ }^{79}$ When unemployment insurance was inaugurated that same year, unemployment was defined thusly: an unemployed person was one who had a work record and was able to work, but who was temporarily shut out of the job market. Only those who had already been employed and had paid into the insurance fund could benefit from the scheme.

75 Dix ans, 193-210.

${ }^{76}$ Bénédicte Zimmermann, "Semantiken der Nicht-Arbeit an der Wende vom 19. zum 20. Jahrhundert: 'Arbeitslosigkeit' und 'chômage' im Vergleich," in Semantiken der Arbeit. Diachrone und vergleichende Perspektiven, ed. Jörn Leonhard and Willibald Steinmetz (Köln: Böhlau, 2016), 269-88, here 270.

77 Ingrid Liebeskind Sauthier, "Modern Unemployment. From the Creation of the Concept to the International Labour Office's First Standards," in Globalizing Social Rights. The International Labour Organization and Beyond, ed. Sadrine Kott and Joël Droux (Basingstoke: Palgrave, 2013), 67-84.

78 "Exposé Ministra Pracy i Opieki Społecznej, wygłoszone na posiedzeniach sejmowej Komisji Obrony Pracy," Praca i Opieka Społeczna 3 (1923): 58-61, here 58.

79 "Prezydent Ministrów Gen. Władisław Sikorski o polityce społecznej w Polsce," Praca i Opieka Spoteczna 3 (1923): 58-61. 
In the Sejm debate, the unemployed worker was assumed to be providing for a family. ${ }^{80}$ The main aim of the scheme was not to erase poverty, but to allow the unemployed person to maintain his status as a worker and his ability to provide for his family. The statute of June 31, 1924, worked the same way as health insurance: the insured worker had to pay contributions in accordance with his wage, but the payment was adjusted to make allowance for the number of his dependent family members. ${ }^{81}$ As for the implementation of the scheme, the unemployment funds were started in September 1924. The system worked well in the big cities, but, in the early days, the Eastern provinces were unable to raise the necessary funds. ${ }^{82}$

Czechoslovakia established unemployment insurance in 1921, following the so-called Gent system. This had been pioneered in Gent in 1901 as voluntary self-insurance administered by non-state public institutions. The model had been established in some other cities and also nationwide in France (1905), Norway (1906), Denmark (1907), the Netherlands (1919) and in 1919 in some parts of Spain. ${ }^{83}$ Czechoslovak unemployment insurance was organized by the trade unions and covered trade union members only. By paying their contributions workers insured themselves against unemployment. In case they lost steady employment, the trade union and the state paid the unemployment benefits in equal shares. Former employees and trade members got fixed amounts for themselves and a double sum if they were married, for a maximum of three months.

Due to economic difficulties, the system did not begin to run until April 1925. Even though the implementation of the Gent system was from the very beginning a compromise by the political parties, with some modifications it remained in force until 1938. However, only one-third to one-half of the working population came under the system. ${ }^{84}$ While the idea behind the Gent system was corporatist (in that it used labor unions as non-governmental third sector institutions for the realization of welfare targets) and the insurance was voluntary, the underlying perception of employment, as well as the model of a male

80 Sprawozdanie stenograficzne ze 141 posiedzenia Sejm Rzeczypospolitej z dnia 2 lipca 1924 r., https:// bs.sejm.gov.pl/exlibris/aleph/a22_1/apache_media/7Y1C2QP27F7JDF2ENSMFX7DCJM2Y17 .pdf.

81 "Ustawa z dnia 18 lipca 1924 r. o zabezpieczeniu na wypadek bezrobocia," Dziennik ustaw Rzeczypospolitej Polskiej, No. 67 (1924): 990-94.

82 Sokal, Social insurance, 96.

83 Jakub Rákosník, “Gentský systém v období I. Československé republiky," Časopis Národního muzea - ŕada historická 170, No. 3-4 (2001): 84-105, here 85.

84 Jakub Rákosník, Odvracená tvár meziválečné prosperity. Nezaměstnanost v Československu v letech 1918-1938 (Praha: Karolinum, 2008), 160-206. 
breadwinner, were similar to those of the various national insurance schemes mentioned above.

What stands out from these few examples is how a defined idea of "proper" work came to be associated with social insurance. Thus, even if the insurance schemes failed in a technical sense, because they did not assure the welfare of all the needy, ideologically they did establish an understanding of "work" and "unemployment" that still prevails.

\section{Conclusion}

Social policy in interwar Poland and Czechoslovakia was forged at the intersection of two currents of influence: the heritage of the German and Austrian models and the impetus for reform supplied by the Versailles order, which highly valued "social peace." Both of the East Central European countries discussed here were deeply involved in the development of national and international social policy and thus provide perfect case studies of the entanglement of the two currents and of the interplay between national and international social policy-making. This widens our perspective on the heritage of European social welfare schemes.

As can be seen from the process of establishing labor standards and extending social insurance schemes, national and international social policies concentrated quite narrowly on the world of work. Whereas general labor standards were more or less wholly formulated at the international level and needed only to be ratified by national parliaments, individual countries had to implement their own internal social insurance schemes. Poland was more effective in the implementation of labor standards, while Czechoslovakia built successfully on a pre-existing heritage of social insurance. Political decisions about eligibility for the insurance scheme came to define what was perceived as "work" and "nonwork," and fixed how we think about those categories. A concentration on work and on providing for families derives from the older German and Austrian systems and has become the European tradition in social policy-making. Despite the institutional and economic obstacles mentioned here, the social policies of the interwar years have not only served as a model for modern systems but have shaped expectations about what they should provide, and to whom. 